www.jmscr.igmpublication.org

Impact Factor (SJIF): 6.379

Index Copernicus Value: 79.54

ISSN (e)-2347-176x ISSN (p) 2455-0450

crossrefDOI: https://dx.doi.org/10.18535/jmscr/v6i12.140

Journal Of Medical Science And Clinical Research

\title{
A Case Report of Recurrent Giant Cell Tumor of Distal end Radius
}

\author{
Authors \\ Dr Anirudh Bansal ${ }^{*}$, Dr Smit Vadher ${ }^{2}$, Dr Arvind Kumar ${ }^{3}$, Dr Sudhir Rawat ${ }^{4}$, \\ Dr Vikramjit Singh ${ }^{5}$ \\ ${ }^{1,5} 3^{\text {rd }}$ Year Resident Doctor, SBKSMIRC, ${ }^{2} 1$ st year Resident Doctor SBKSMIRC \\ ${ }^{3}$ Associate Professor SBKSMIRC, ${ }^{4}$ Assistant Professor SBKSMIRC \\ *Corresponding Author \\ Dr Anirudh Bansal \\ $3^{\text {rd }}$ year Resident Doctor, Orthopaedics Department, SBKSMIRC \\ Sumandeep Vidyapeeth, Vadodara Gujrat, India
}

\section{Introduction}

It is a common, locally aggressive benign bone tumour, constituting $5 \%$ of all skeletal tumours generally seen in $3^{\text {rd }}$ decade of life with female preponderance. Most common site for GCT is in epiphysio-metaphyseal region with $15 \%$ propensity for local recurrence after surgical treatment.GCT of bone is very rarely seen in children and adults older than 65 years of age. GCT occur in approximately one person per million per year. Usually the tumour site is at the long bone meta-epiphysis, especially the distal end radius, femur proximal humerus and tibia.

Giant Cell Tumour (GCT) of bone is benign and locally aggressive tumour. It represents approximately $3 \%$ to $5 \%$ of all primary tumour. It generally occurs in adults between the age of 2040 years. We report the case of a distal end radius GCT diagnosed in a 35 year old male. It was treated with radical excision, fibular grafting and dynamic compression plating with $\mathrm{K}$-wire fixation. Wrist was immobilised with above elbow slab. K-wire removed after 6 weeks and wrist mobilisation started.

\section{Case Presentation}

35 year old male presented with recurrence of swelling on dorsal aspect of wrist and forearm (size approx. $10 \times 6 \mathrm{cms}$ ) after 1 year of primary surgical treatment in the form of Currettage, Chemical cauterization (used phenol) and Reconstructed by sandwich technique. Now the case was treated with radical excision of tumour, reconstruction of radius and wrist using contralateral proximal fibular graft; fixed with dynamic compression plate and K-wire. Limb was immobilised with above elbow slab. K-wire removed after 6 weeks and wrist mobilisation started. Many literatures shows that Simple curettage of giant-cell tumour is associated with a $5 \%$ to $15 \%$ rate of local recurrence. Recurrence rate decrease with adjuvant treatment of bone bed with chemical cauterization, use of bone cement and bone graft (sandwich technique). But in our case, despite initial treatment was given in form of curettage, chemical cauterization (used phenol) and reconstruction by sandwich technique (BG $\rightarrow$ Gel Foam $\rightarrow$ Bone cement) lesion recurred. So we used this techniques to remove the tumour and 
reconstruct the radius and wrist to preserve the of forearm. wrist movement along with maintenance of length

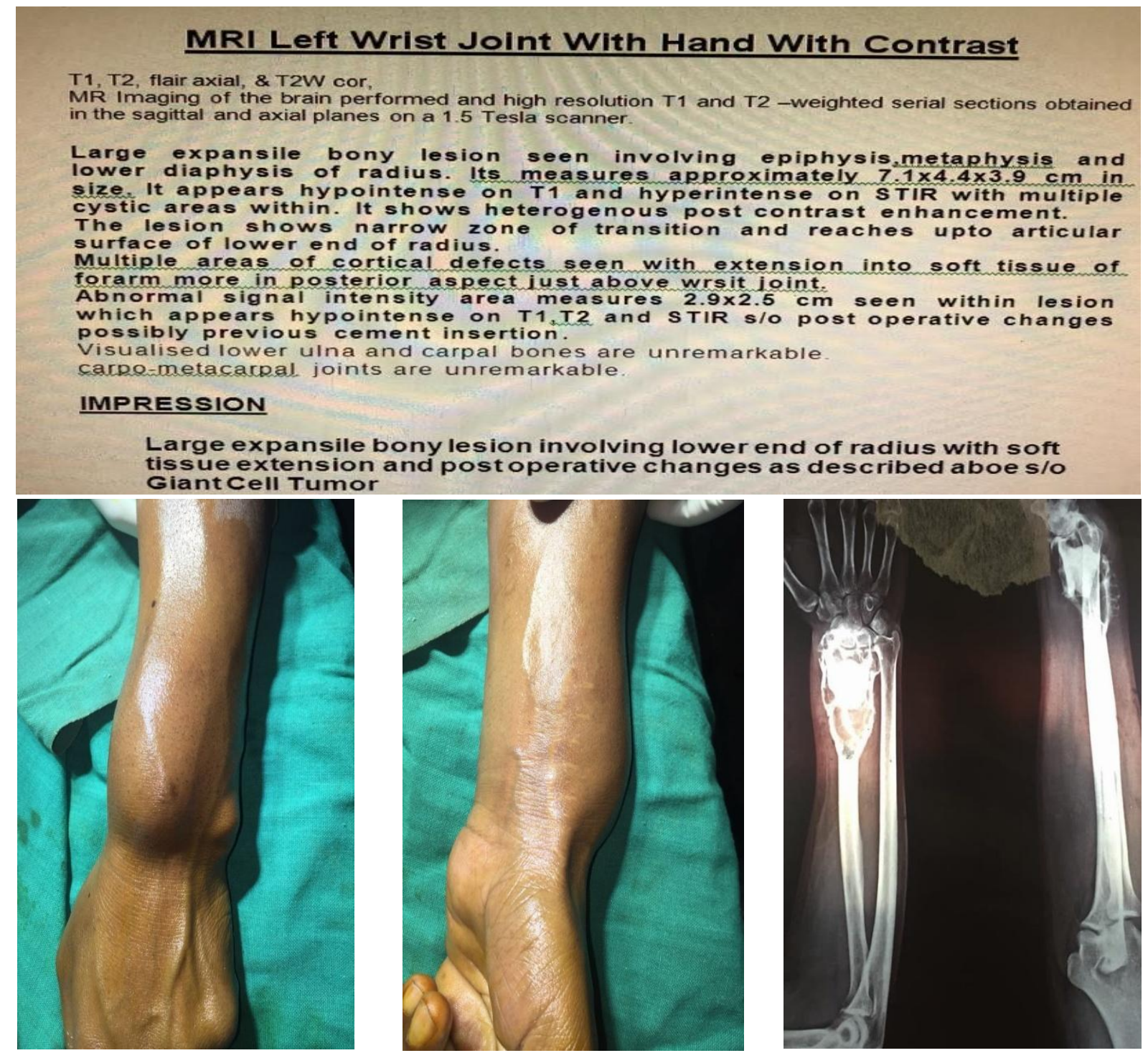

\section{Result}

Radical resection and reconstruction with autologous contralateral proximal fibular graft, internal fixation with dynamic compression plate gives cosmetically and functionally satisfactory outcome.

\section{Discussion}

Giant Cell Tumour of bone may present with pain and swelling over and around the joint. About 10$15 \%$ patient will present with pathological fracture. Many authors reported that GCT of distal radius is particularly aggressive and has a high rate of local recurrence. It can also metastasize to the lung (less than $2 \%$ ). $10 \%$ of the GCT of bone involves the distal end radius. The goal of our treatment in this case is not only to completely resect the tumour but also decrease the chances of recurrence and preserve the joint function and length of forearm. Other treatment modalities have been advocated for recurrent giant-cell tumour of bone like

1. Resection followed by allograft, autograft or prosthetic reconstruction

2. Resection of tumour and centralization of ulna,

3. Resection of tumour and wrist arthrodesis etc. 


\section{JMSCR Vol||06||Issue||12||Page 870-874||December
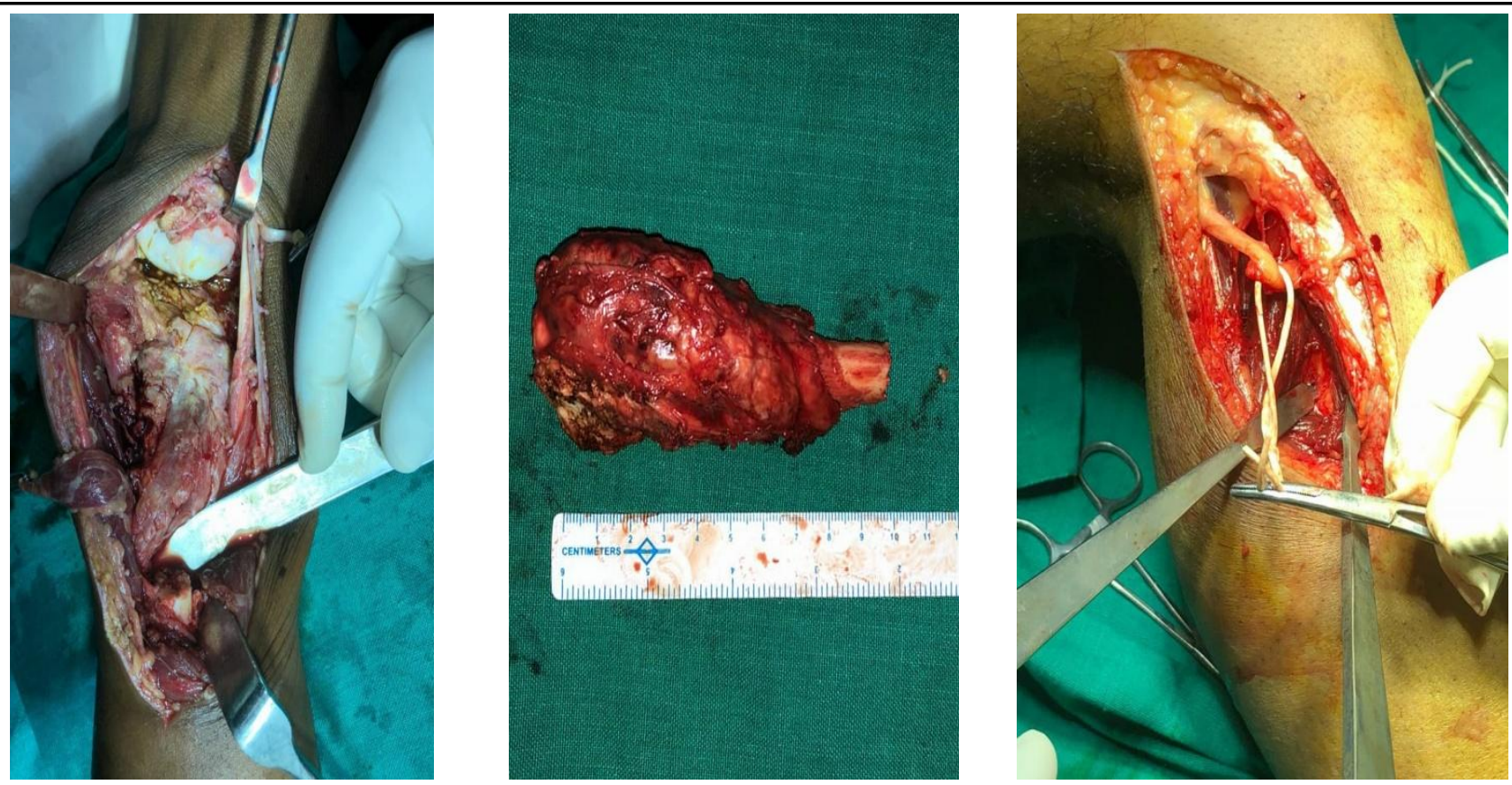

Simple curettage of giant-cell tumour is associated with a $5 \%$ to $15 \%$ rate of local recurrence. Adjuvant treatment of bone bed with chemical cauterization and reconstruction by sandwich technique decrease the incidence of recurrence.
The extent of the osteonecrosis induced by chemical cauterization and bone cement is helpful to kill the tumour cells but this may weaken the bone which leads to pathological fracture.
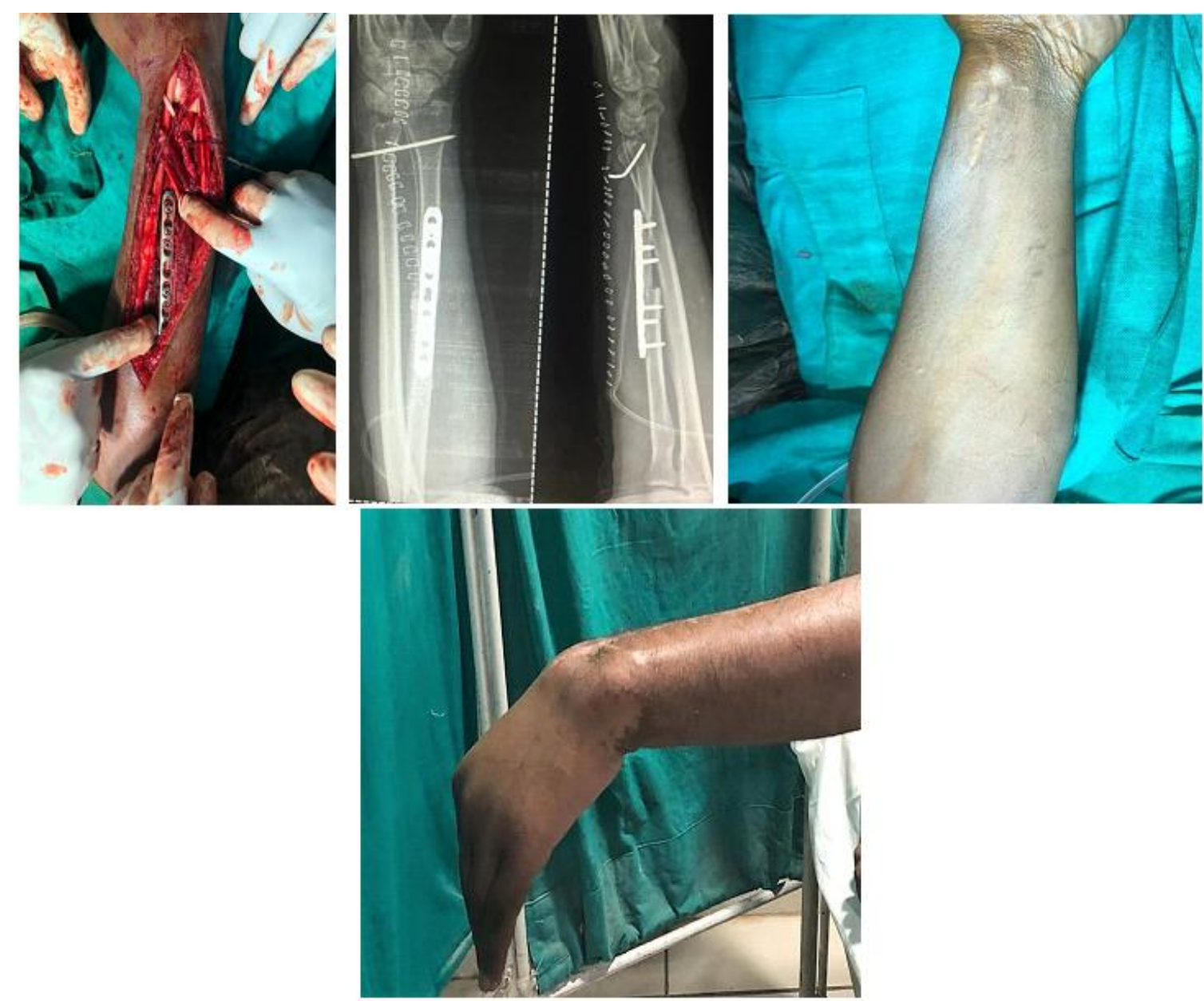


\section{Conclusion}

Diagnosis of GCT is difficult and requires a great deal of experience, especially in young patients. Osteolytic lesion incidentally found at a long bone epiphysis, can be misinterpreted.

\section{References}

1. Eckardt, J.J. and Grogan, T.J. (1986) Giant Cell Tumour of Bone. Clinical Orthopaedics and Related Research, 204,45-58.

2. Dahlin, D.C., Cupps, R.E. and Johnson Jr., E.W. (1970) Giant Cell Tumour: A Study of 195 Cases. Cancer, 25,1061-1070. http://dx.doi.org/10.1002/10970142(197005)25:5<1061::AIDCNCR2820250509>3.0.CO;2-E

3. Goldenberg, R.R., Campbell, C.J. and Bonfiglio, M. (1970) Giant Cell Tumour of Bone: An Analysis Two Hundred and Eighty Cases. Journal of Bone and Joint Surgery, 52, 619-664.

4. Smith, R.J. and Mankin, H.J. (1977) Allograft Replacement of Distal Radius for Giant Cell Tumor. Journal of Hand Surgery, 2, 299-309. http://dx.doi.org/10.1016/S03635023(77)80131-7

5. Campanacci, M., Baldini, N., Boriani, S. and Sudanese, A. (1987) Giant Cell Tumour of Bone. Journal of Bone and Joint Surgery, 69, 106-114.

6. Clohisy, D.R. and Mankin, H.J. (1994) Osteoarticular Allograft for Reconstruction after Resection of a Musculoskeletal Tumour in the Proximal End of the Tibia. Journal of Bone and Joint Surgery, 76, 334-349.

7. Vander Griend, R.A. and Funderburk, C.H. (1993) The Treatment of Giant-Cell Tumours of the Distal Part of the Radius. Journal of Bone and Joint Surgery, 73, 899-908.

8. Walthar, M. (1911) Resection de extremiteinferieure $\mathrm{du}$ radius pour osteosarcoma

geffe

de

I

extremitesuperiuete du perone. Sac Chir Par Bull Mem, 37, 739-747.

9. Campanacci, M. (1976) Giant Cell Tumor and Chondrosarcoma: Grading, Treatment and Results. Recent Results in Cancer Research, 54, 257-261.

10. Schajowicz, F. (1961) Giant-Cell Tumors of Bone (Osteoclastoma): A Pathological and Histochemical Study. Journal of Bone and Joint Surgery, 43, 1-29.

11. Szendroi, M. (2004) Giant Cell Tumor of Bone. Journal of Bone and Joint Surgery (British Volume), 86, 5-12.

12. O'Donnell, R.J., Springfield, D.S., Motwani, H.K., Ready, J.E., Gerhart, M.C. and Mankin, H.J. (1994) Recurrence of Giant Cell Tumours of Long Bones after Curettage and Packing with Cement. Journal of Bone and Joint Surgery (America Volume), 76, 1827-1833.

13. Cheng, C.Y., Shih, H.N., Hsu, K.Y. and Hsu, R.W. (2001) Treatment of Giant Cell Tumour of the Distal Radius. Clinical Orthopaedics and Related Research, 383, 221-228.

http://dx.doi.org/10.1097/00003086200102000-00026

14. Vander Griend, R.A. and Funderburk, C.H. (1993) The Treatment of Giant-Cell Tumors of the Distal Part of the Radius. Journal of Bone and Joint Surgery (America Volume), 75, 899-908.

15. Malawer, M.M. and Dunham, W. (1991) Cryosurgery and Acrylic Cementation as Surgical Adjuncts in the Treatment of Aggressive (Benign) Bone Tumors: Analysis of 25 Patients, 262, 42-57.

16. Hussain, P. and Singh, V. (2007) Giant Cell Tumor of Distal Radius: A Case Report and Description of Surgical Technique. The Internet Journal of Orthopaedics, 8, Number 2.

17. Pho, R.W. (1981) Malignant Giant Cell Tumour of Distal End of the Radius 
Treated by a Free Vascularized Fibular Transplant. Journal of Bone and Joint Surgery (America Volume), 63, 877-884.

18. Asavamongkolkul, A., Waikakul, S., Phimolsarnti, R. and Kiatisevi, P. (2009) Functional Outcome Following Excision of a Tumour and Reconstruction of Distal Radius. International Orthopaedics, 33, 203-209.

http://dx.doi.org/10.1007/s00264-007-

0441-7

19. Deb, H.K. and Das, N.K. (1992) Resection and Reconstructive Surgery in Giant Cell Tumour of Bone. Indian Journal of Orthopaedics, 26, 13-16. 